\title{
Analisa Perubahan Ionosfer Akibat Gempa Bumi Sumatra Barat Tanggal 2 Maret 2016
}

\author{
Febrian Adi Saputra dan Mokhamad Nur Cahyadi \\ Departemen Teknik Geomatika, Fakultas Teknik Sipil dan Perencanaan, Institut Teknologi Sepuluh Nopember (ITS) \\ e-mail: cahyadi@geodesy.its.ac.id
}

\begin{abstract}
Abstrak -Pada saat gempa bumi terjadi, ada tiga jenis gelombang yang dihasilkan, yaitu : (1) Gelombang Acoustic (kecepatan 1 $\mathrm{km} / \mathrm{s}$ ) yang dihasilkan dekat dari pusat gempa bumi, gelombang tersebut menyebar dan naik hingga ketinggian lapisan $F$ di ionosfer dalam waktu 10 menit atau lebih. (2) Gelombang gravity (kecepatan $0.3 \mathrm{~km} / \mathrm{s}$ ) yang dihasilkan dari gelombang tsunami akibat dari gempa bumi yang besar, dan (3) Gelombang Rayleigh (kecepatan $4 \mathrm{~km} / \mathrm{s}$ ) yang dihasilkan dari gelombang permukaan dan merambat menjauh mengelilingi bumi dari pusat gempa bumi. Gelombang Acoustic yang dihasilkan secara tegak lurus dari kerak bumi selama gempa merambat ke ionosfer, lalu membuat penyimpangan kerapatan elektron. Fenomena ini terdeteksi sebagai CIDs (Coseismic Ionosphere Disturbances), yaitu fluktuasi TEC yang terjadi 15 menit hingga 1 jam setelah gempa terjadi. Akibat dari penyimpangan tersebut, gelombang elektromagnetik yang dipancarkan oleh satelit GNSS akan mengalami delay ketika melewati ionsfer kira-kira $300 \mathrm{~km}$ dari permukaan bumi. Variasi ionosfer diamati pada saat time-delay ini berdasarkan kuantitas Total Electron Content (TEC). Nilai TEC dinyatakan dalam TECU, dimana 1 TECU sama dengan $10^{16}$ elektron $/ \mathrm{m}^{2}$. Nilai anomali TEC tersebut akan menggambarkan besaran gangguan akibat adanya gempa. Indonesia sebagai negara yang sering terjadi gempa, perlu dilakukan pemantauan untuk mengetahui perubahan atmosfer akibat gempa, salah satunya yaitu dengan analisa TEC pada lapisan ionosfer. Dalam penelitian ini dilakukan pengamatan perubahan TEC dua hari sebelum, saat, dan dua hari sesudah terjadinya gempa bumi di Sumatra Barat pada tanggal 2 Maret 2016 dengan metode pengolahan data GNSS dari stasiun CORS milik Badan Informasi Geospasial (BIG) yang berada di daerah Sumatra, yaitu stasiun CAIR, CBKT, CPAR, CPDG, dan CSEL. Hasil dari pengolahan data menunjukkan anomali TEC muncul pada waktu 11 - 15 menit setelah gempa dengan besar anomali 1,5 - 3,5 TECU yang direkam oleh satelit GPS nomor 17 dan 0,5 - 1,7 TECU yang direkam oleh satelit Glonass nomor 14.
\end{abstract}

Kata Kunci-Gempa bumi, GNSS, Ionosfer, Total Electron Content.

\section{PENDAHULUAN}

$\mathrm{K}$ EPULAUAN di Indonesia terletak pada tiga batas lempeng tektonik utama, yaitu lempeng Indo-Australia, Pasifik, dan Eurasia, membentang dari Sumatera bagian barat sampai Papua bagian timur. Lajur subduksi Sumatra merupakan lajur tempat Lempeng Indo-Australia menunjam ke bawah Lempeng Eurasia. Lempeng Indo-Australia bergerak ke arah utara dengan kecepatan relatif terhadap lempeng Eurasia sebesar $7 \mathrm{~cm} /$ tahun. Akibat dari pergerakan lempeng tersebut maka Indonesia sering disebut berada pada daerah Ring of Fire, yaitu daerah cincin api atau yang sering mengalami gempa bumi dan letusan gunung berapi. Pergesekan pada lajur
Benioff pada lempeng yang menunjam menyebabkan aktivitas pergerakan lempeng sepanjang Pulau Sumatra yang muncul sebagai deretan daerah gempa bumi [1].

Untuk memantau perkembangan gempa, studi teknik geodesi/geomatika sangat berperan, yaitu teknologi GNSS yang digunakam untuk monitoring pergerakan lempeng bumi dan efek yang terjadi di lapisan ionosfer dengan memanfaatkan satelit GNSS. Salah satu precursor anomaly yang terjadi sebelum gempa didapatkan dari pengukuran variasi Total Electron Content (TEC) menggunakan data Global Positioning System (GPS) [2]. Pada dasarnya perhitungan TEC akibat gempa dapat diklasifikasikan dalam dua jenis, yaitu preseismic dan Coseismic Ionospheric Disturbance (CID). Fenomena pre-seismic anomaly ini berlangsung 1-2 minggu hingga 1 jam sebelum terjadinya gempa sedangkan CID terjadi 15 menit hingga satu jam setelah gempa terjadi. Fluktuasi pada CID dapat digunakan sebagai early warning sebelum tsunami datang. Pergerakan dari gelombang tsunami ini cukup lambat, sekitar 600-700 km/jam. Apabila gelombang tsunami ini dapat dideteksi di laut lepas, terdapat cukup waktu untuk dilakukan evakuasi menuju ke tempat yang lebih tinggi[3].

Gempa bumi akan membentuk dan merambatkan tiga energi gelombang, yaitu : Acoustik, Gravity, dan Reyligh. Gelombang Acoustic (kecepatan $1 \mathrm{~km} / \mathrm{s}$ ) dihasilkan dekat dari pusat gempa bumi, lalu menyebar ke atas dan mencapai diketinggian lapisan F ionosfer dalam waktu 10 menit atau lebih. Gelombang Gravity (kecepatan $0.3 \mathrm{~km} / \mathrm{s}$ ) dihasilkan dari gelombang tsunami akibat dari gempa bumi yang besar, dan Gelombang Rayleigh (kecepatan $4 \mathrm{~km} / \mathrm{s}$ ) dihasilkan dari gelombang permukaan yang merambat menjauh dari pusat gempa. Gelombang Acoustic yang dihasilkan secara tegak lurus dari kerak bumi selama gempa merambat ke ionosfer membuat penyimpangan dari kerapatan elektron terdeteksi sebagai CIDs (Coseismic Ionosphere Disturbances). Akibatnya, gelombang elektromagnetik yang dipancarkan oleh satelit GNSS akan mengalami delay ketika melewati ionsfer kira-kira $300 \mathrm{~km}$ dari permukaan bumi. Variasi ionosfer diamati pada saat timedelay ini, berdasarkan kuantitas TEC. Nilai TEC biasanya dinyatakan dalam TECU, dimana 1 TECU sama dengan $10^{16}$ elektron $/ \mathrm{m}^{2}$. Semakin besar magnitudo gempa yang terjadi maka gangguan yang akan dihasilkan pada atmosfer akan besar juga. Hal ini disebabkan karena besarnya energi tersebut dapat mengganggu densitas elektron yang ada di ionosfer hingga radius $400 \mathrm{~km}$ dari pusat gempa [4].

Dalam penelitian sebelumnya yang pernah dilakukan oleh Septiningrum [5], yaitu mengamati variasi perubahan ionosfer setelah terjadinya gempa akibat gempa di Mentawai menggunakan data Sumatra GPS Array (SUGAR), sedangkan 
dalam penelitian yang dilakukan ini adalah mengamati perubahan ionosfer, yakni Coseismic Ionospheric Disturbance (CID) anomali TEC ketika terjadi gempa bumi di Sumatra Barat pada tanggal 2 Maret 2016 yang magnitude-nya sebesar 8,3SR dengan pengolahan data GNSS dari stasiun milik Badan Informasi Geospasial (BIG) yang berada di daerah Sumatra.

\section{METODOLOGI PENELITIAN}

\section{A. Lokasi Penelitian}

Lokasi penelitian ini dilakukan pada stasiun pengamatan CORS-GPS milik BIG yang dekat lokasi gempa dengan epicenter 5 9' 36" Lintang Selatan dan 94 3' Bujur Timur [6]. Stasiun pengamatan tersebut adalah CAIR, CBKT, CPAR, CPDG, dan CSEL dengan detail posisi yang dijelaskan pada gambar 1 dan Tabel 1. Pengamatan dilakukan dua hari sebelum, saat terjadi, dan dua hari setelah gempa bumi pada tanggal 2 Maret 2016.

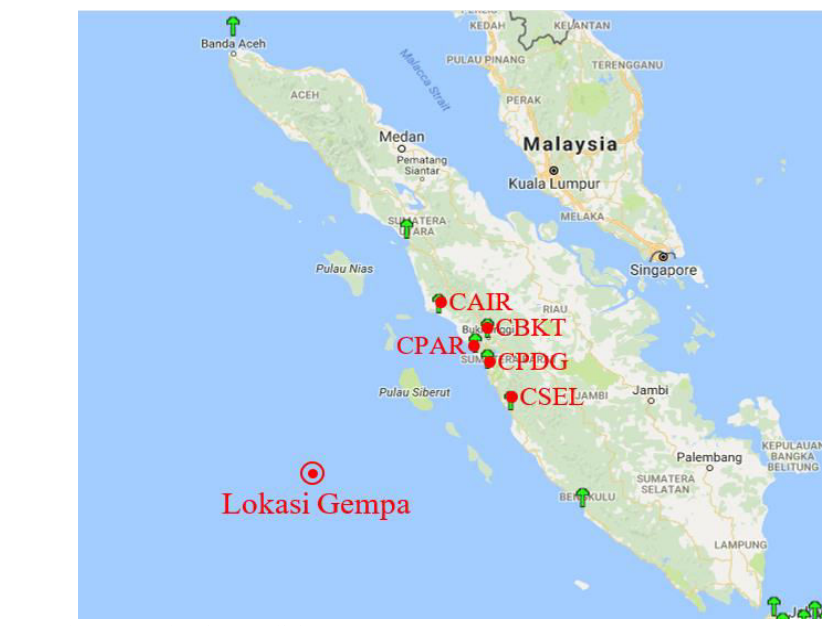

Gambar 1. Lokasi Penelitian CORS-GPS (Inacors-BIG, 2017).

Tabel 1.

Data Stasiun CORS-GPS BIG di Pulau Sumatra

\begin{tabular}{ccc}
\hline \hline No. & Nama Stasiun & Posisi \\
\hline 1 & CAIR & $0^{\circ} 12^{\prime} 28.79123^{\prime \prime} \mathrm{N}, 99^{\circ} 23^{\prime} 40.38657^{\prime \prime} \mathrm{E}$ \\
2 & CPAR & $0^{\circ} 37^{\prime} 30.45553^{\prime \prime} \mathrm{S}, 100^{\circ} 7^{\prime} 55.23985^{\prime \prime} \mathrm{E}$ \\
3 & CBKT & $0^{\circ} 18^{\prime} 32.21234^{\prime \prime} \mathrm{S}, 100^{\circ} 22^{\prime} 15.93776^{\prime \prime} \mathrm{E}$ \\
4 & CPDG & $0^{\circ} 57^{\prime} 14.33568^{\prime \prime} \mathrm{S}, 100^{\circ} 21^{\prime} 47.20308^{\prime \prime} \mathrm{E}$ \\
5 & CSEL & $1^{\circ} 47^{\prime} 53.27004^{\prime \prime} \mathrm{S}, 100^{\circ} 50^{\prime} 20.93676^{\prime \prime} \mathrm{E}$ \\
\hline \hline
\end{tabular}

B. Data dan Peralatan

\section{Data}

Data yang dibutuhkan dalam penelitian ini adalah :

a. Data rinex observasi (pada tanggal 29 Februari 2016, 1-4 Maret 2016, atau 60 doy hingga 64 doy) dari stasiun GPS yang diperoleh dari BIG

b. Data Navigasi Satelit, diunduh dari: (http://garner.ucsd.edu/pub/nav)

c. Data program rdrnx.f dan rdeph.f, diunduh dari: (https://ep.sci.hokudai.ac.jp/ heki/software.htm)

\section{Peralatan}

Peralatan yang digunakan pada penelitian ini dibagi menjadi dua, yakni: a. Perangkat Keras (Hardware), terdiri dari Laptop Lenovo B40-45 dengan spesifikasi sistem 64-bit, prosesor AMD A8-6410 APU with AMD Radeon R5 Graphics, dan RAM 6GB.

b. Perangkat Lunak (Software)

- Sistem Operasi Windows 10 dan Linux Ubuntu 14.04 LTS.

- Bahasa Pemrograman Fortran.

- MATLAB R2014a

- Microsoft Office (Ms. Word, Ms. Excel, dan Ms. Visio).

\section{Diagram Alir Penelitian}

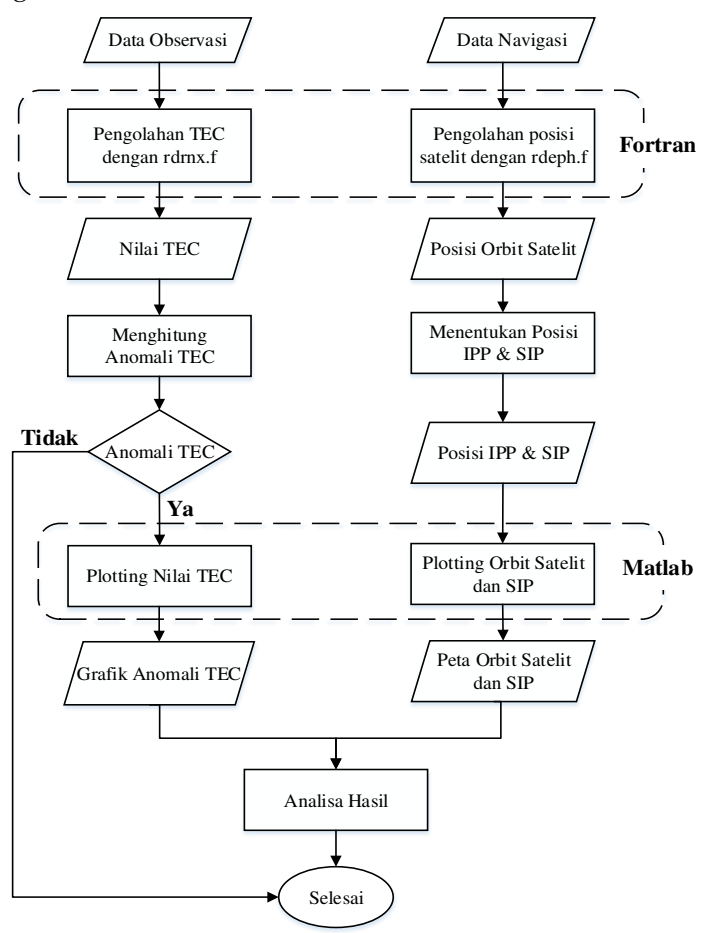

Gambar 2. Diagram Alir Pengolahan Data.

Berikut adalah penjelasan diagram alir tahapan pengolahan data :

a. Data

Data Observasi GNSS didapatkan data dari instansi Badan Informasi Geospasial (BIG) dalam bentuk RINEX yaitu data pada tanggal 29 Februari , 1 - 4 Maret 2016 (atau 60 doy hingga 64 doy). Sedangkan untuk data navigasi didapatkan dari website Sopac, dengan alamat http://garner.ucsd.edu/pub/nav lalu mendownload data doy yang sama dengan data observasinya. Data navigasi yang didownload adalah broadcast ephimeris orbit satelit (".n" untuk GPS dan ".g” untuk Glonass). Data ini digunakan untuk menentukan posisi orbit satelit dengan menggunakan elemen-elemen keplerian yang akan diproyeksikan ke bumi.

b. Pengolahan Data GNSS

Melakukan pengolahan data RINEX Observasi menggunakan program rdrnx.f untuk mendapatkan waktu dan besar nilai STEC di setiap stasiun pengamatan dan data RINEX Navigasi diolah menggunakan program rdeph.f untuk mendapatkan posisi orbit satelit yang melintas pada 
hari pengamatan. Pengolahan data ini dijalankan pada aplikasi Fortran pada sistem operasi Ubuntu 14.04 LTS

c. Perhitungan Anomali TEC

Setelah didapatkan nilai STEC, kemudian dilakukan perhitungan untuk mengetahui perubahan nilai (VTEC) Vertical Total Electron Content secara relative, yaitu dengan mengurangkan nilai STEC yang telah didapat dengan perataannya/polynomial pangkat enam. Anomali TEC didapatkan bila ada simpangan dari data satu periode bernilai lebih besar dari median-nya. Jika data tersebut terdapat anomali TEC maka dinyatakan ada gangguan pada lapisan ionosfer, sehingga dilanjutkan dengan pengeplotan hasil anomali tersebut pada aplikasi Matlab untuk menampilkan visualisasi grafik perubahan TEC tersebut.

d. Penentuan Posisi IPPP dan SIP

Posisi orbit satelit yang telah didapatkan dari pengolahan menggunakan program rdeph.f pada aplikasi Fortran kemudian dilanjutkan pengolahan menentukan posisi Ionospheric Pierce Point (IPP) dan Sub-Ionospheric Point (SIP) untuk mengetahui posisi orbit satelit yang merekam TEC saat gempa terjadi. Pengolahan ini dilakukan menggunakan aplikasi Matlab yang hasilnya adalah plotting posisi SIP di permukaan bumi.

e. Pengeplotan pada Matlab

Pengeplotan ini adalah untuk memvisualisasikan hasil pengolahan data, yanag pertama yaitu nilai anomali TEC di setiap stasiun pengamatan, dan yang kedua adalah posisi orbit satelit GNSS yang melintas saat gempa terjadi serta SIP di permukaan bumi. Pengeplotan ini dilakukan menggunakan aplikasi Matlab R2014A yang bekerja pada sistem operasi Windows. Setelah didapatkan gambar hasil pengeplotan, kemudian dilanjutkan analisa besar nilai anomali TEC pada ionosfer dan dihubungkan dengan posisi SIP satelit yang melintas pada saat gempa terjadi.

\section{HASIL DAN ANALISA}

\section{A. Pengolahan Data Rinex GPS dengan Fortran}

Data Observasi didapatkan dari BIG dalam bentuk RINEX (Receiver Independent Exchange Format), kemudian diolah menggunakan program rdrnx.f, sedangkan data Navigasi didapatkan dari ftp://garner.ucsd.edu/pub/products kemudian diolah menggunakan program rdeph.f yang dijalankan dengan software Fortran pada Sistem Operasi Linux Ubuntu.

Hasil pengolahan data observasi adalah data waktu (UTC) dan STEC (TECU) dengan interval waktu 30 detik pada satelit yang terekam di setiap stasiun pengamatan. Sedangkan hasil pengolahan data navigasi (broadcast ephemeris) adalah waktu (UTC) dengan interval 3 menit dan posisi orbit satelit.

\section{B. Lintasan Satelit}

Gempa di Sumatra Barat terjadi pada tanggal 2 Maret 2016 pukul 19.49 WIB atau 12.49 UT dimana pusat gempa berada di sekitar $682 \mathrm{~km}$ barat daya Mentawai tepatnya pada koordinat $5^{\circ} 9^{\prime} 36^{\prime \prime} \mathrm{LS}$ dan $94^{\circ} 3^{\prime} \mathrm{BT}$ dengan magnitudo sebesar 8,3SR pada kedalaman sekitar $10 \mathrm{~km}$.

Pada masa-masa gempa tersebut, kami mengamati gangguan ionosfer menggunakan data Observasi GPS-CORS dari BIG
(Badan Informasi Geospasial) yang berada di Pulau Sumatra dan dekat dengan lokasi gempa. Pengamatan ini dilakukan selama kurun waktu lima hari yaitu dua hari sebelum gempa, saat terjadinya gempa, dan dua hari setelah terjadinya gempa. Tujuan dari pengamatan di beberapa stasiun GPS-CORS tersebut dilakukan untuk mendapatkan nilai perubahan TEC yang diakibatkan dari gempa.

Gempa bumi dapat menimbulkan dorongan energi gelombang acoustic, gravity dan rayleigh, serta momentum secara tiba - tiba yang akan menghasilkan gangguan pada lapisan atmosfer yang dapat menyebabkan terjadinya fluktuasi atau variasi TEC pada lapisan ionosfer. Semakin besar tekanan yang terjadi maka gangguan yang akan dihasilkan pada atmosfer akan besar juga. Hal ini disebabkan karena besarnya energi tersebut dapat mengganggu densitas elektron yang ada di ionosfer hingga radius $400 \mathrm{~km}$ dari pusat letusan ${ }^{[3]}$.

Waktu delay pada saat di lapisan ionosfer dapat dihitung dengan mengkombinasikan dua frekuensi reciver GNSS, untuk memperoleh nilai Total Electron Content (TEC). Dengan menghitung modulasi sinyal pada gelombang pembawa, $f_{l}=$ 1575.42MHz dan $f_{2}=1227.6 \mathrm{MHz}$. Setelah mengkombinasikan nilai pseudorange dan carrier phase dual frekuensi, TEC dapat dihitung dengan rumus berikut ini:

$$
\delta S T E C=\frac{f_{1}^{2} \cdot f_{2}^{2}}{40.28 \cdot\left(f_{2}^{n}-f_{1}^{2}\right)} \cdot\left(\delta \mathrm{L}_{1}-\delta \mathrm{L}_{2}\right)
$$

Dimana $\delta \mathrm{STEC}, \delta \mathrm{L}_{1}, \delta \mathrm{L}_{2}$ adalah selisih nilai STEC, jarak fase $\mathrm{L}_{1}$ dan $\mathrm{L}_{2}$ antara dua epok yang berurutan.

Hasil dari pengamatan di lima stasiun yang berapa di sekitar gempa bumi menggunakan satelit GPS selama dua hari sebelum, saat terjadi, dan dua hari sesudah terjadinya gempa didapatkan bahwa anomali TEC yang signifikan terdapat pada hari saat terjadinya gempa. Hal ini bisa dilihat dengan visualisasi orbit satelit yang melintas di daerah sekitar gempa yang akan ditampilkan pada Gambar 3 .

Gambar 3 adalah hasil dari proyeksi lintasan satelit GPS saat terjadinya gempa, dapat dilihat bahwa satelit yang mengorbit saat gempa terjadi adalah satelit nomor 3, 7, 9, 17, dan 23. Tetapi hasil dari perhitungan nilai anomali TEC menunjukkan bahwa sinyal satelit yang dapat merekam fluktuasi TEC di lapisan ionosfer adalah satelit nomor 17, hal ini dikarenakan orbit satelit yang paling dekat dengan pusat gempa adalah sateli nomor 17. Data anomali TEC tersebut juga muncul di semua stasiun pengamatan, yaitu stasiun CAIR, CBKT, CPAR, CPDG, dan CSEL yang merupakan stasiun CORS-GPS milik BIG.

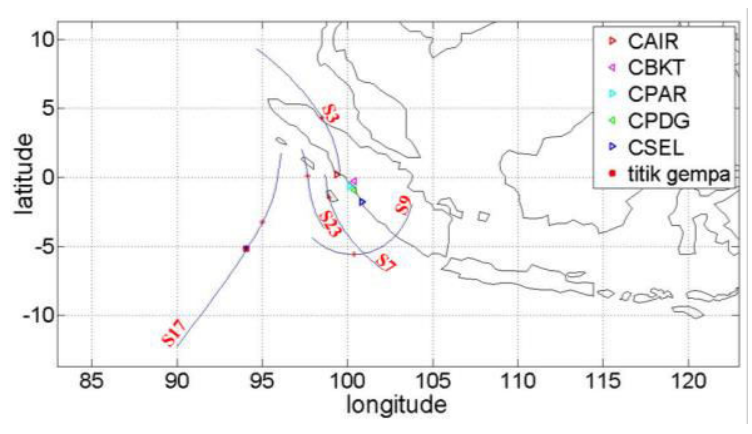


Gambar 3. Orbit Satelit Saat Gempa Terjadi Pada Tanggal 2 Maret 2016 Pukul 11.00-14.00UT.

Perambatan sinyal satelit GPS dengan ketinggian 20.000 $\mathrm{km}$ dari permukaan bumi disebut dengan line of sight. Perpotongan LOS dengan ionosfer pada keadaan data (300 $\mathrm{km})$ disebut dengan IPP (Ionospheric Pierce Point). Ketinggian tersebut termasuk dalam lapisan F-layer, dimana arah pergerakan satelit dapat digambarkan. Dan proyeksi IPP ke atas permukaan tanah disebut Sub-Ionospheric Point (SIP). SIP ini sangatlah penting dianalisa ketika akan melakukan perhitungan TEC [4].

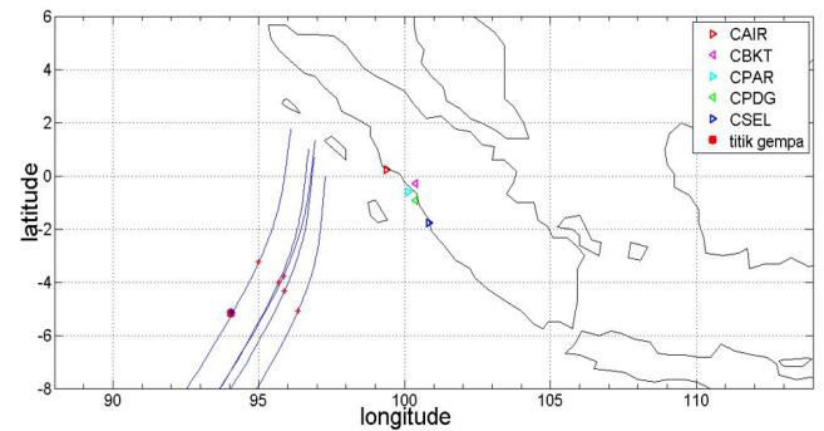

Gambar 4. Orbit Satelit GPS Nomor 17 yang Dipetakan Melalui SIP di Semua Stasiun Pukul 11.00-14.00UT.

Garis biru merupakan alur proyeksi lintasan satelit, simbol bulat merah menunjukkan epicenter dan titik merah menandakan waktu gempa terjadi (IPP point). Simbol segitiga adalah stasiun CORS-GPS milik BIG yang dijelaskan dalam legenda. Pada saat terjadi gempa satelit nomor 17 melintas di sebelah barat Pulau Sumatra.

\section{Plotting Perubahan TEC}

Hasil plotting anomali TEC adalah sebagai berikut:

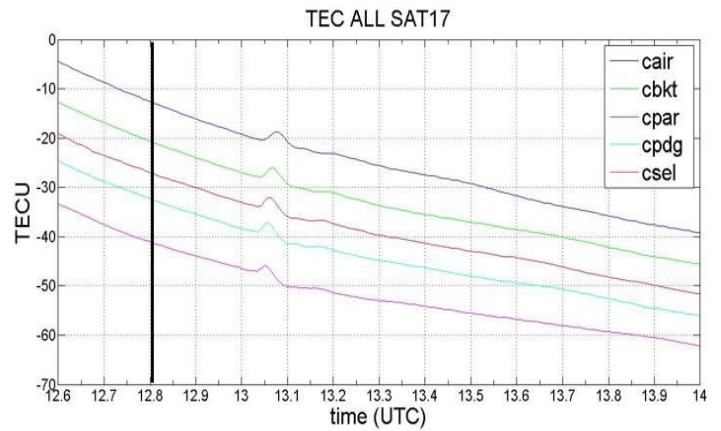

Gambar 5. STEC Satelit GPS Nomor 17 di Semua Stasiun Pengamatan pada Tanggal 2 Maret 2016.

Pada gambar 5 menunjukkan bahwa gempa terjadi pada pukul 12:49 UT (garis hitam vertikal). Berdasarkan grafik diatas nampak adanya fluktuasi di lapisan ionosfer di semua stasiun pengamatan dari sinyal yang dibawa oleh satelit nomor 17. Fluktuasi tersebut muncul sekitar 15 menit setelah gempa terjadi.

Setelah diketahui nomor satelit yang dapat menampilkan fluktuasi saat terjadinya gempa, langkah selanjutnya adalah menghitung nilai VTEC, yaitu dengan mengurangkan nilai STEC yang telah didapat dengan perataannya/polynomial pangkat enam.

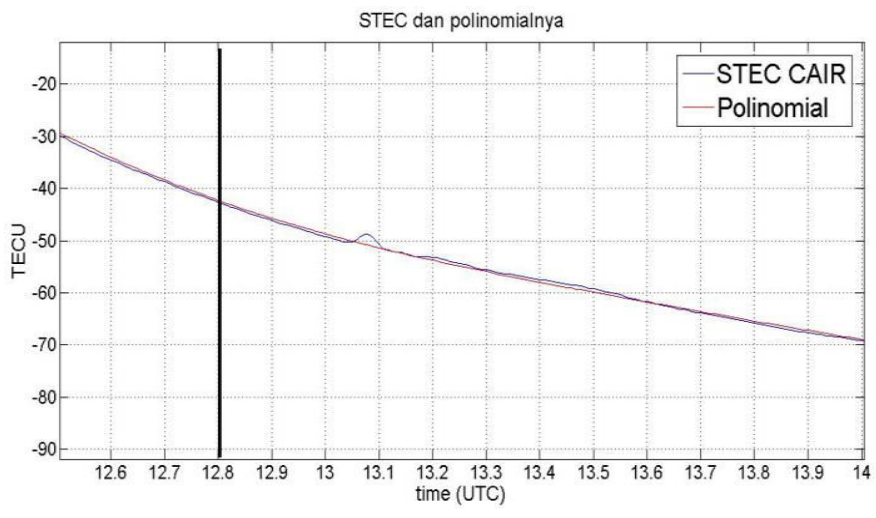

Gambar 6. STEC dengan Polinomial Pangkat Enam di Stasiun CAIR.

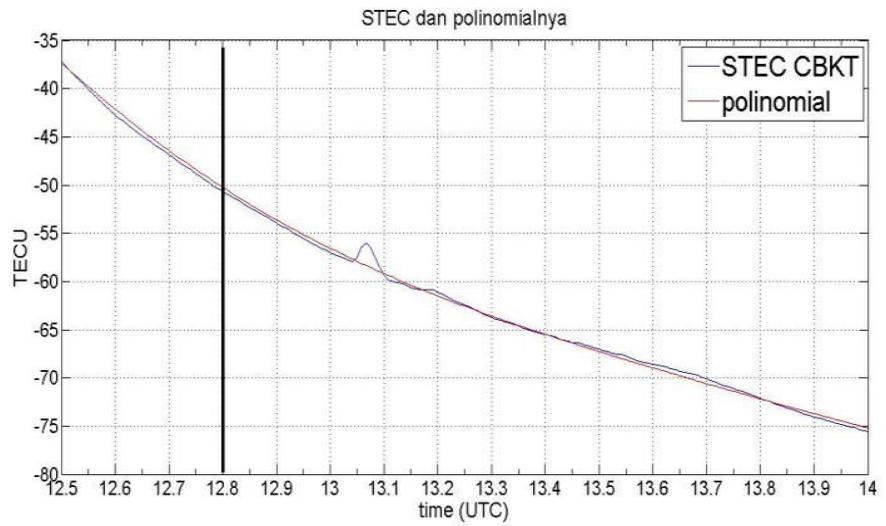

Gambar 7. STEC dengan Polinomial Pangkat Enam

di Stasiun CBKT.

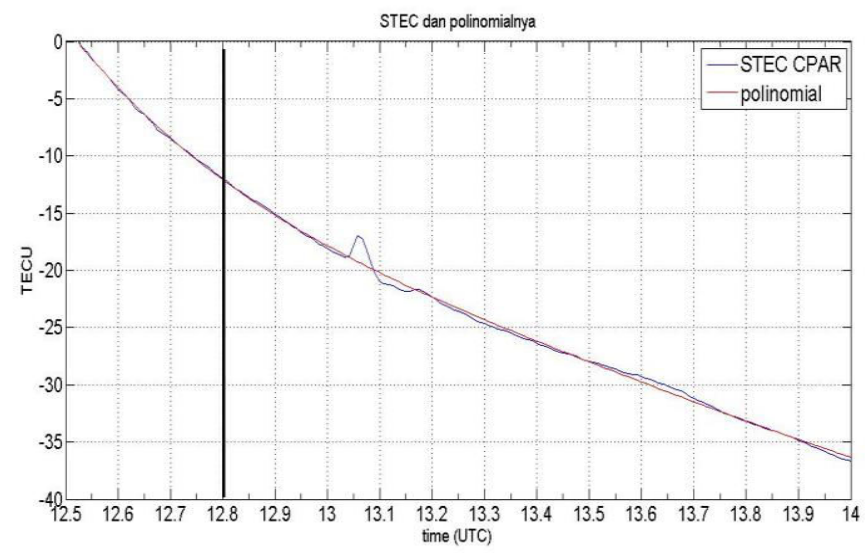

Gambar 8. STEC dengan Polinomial Pangkat Enam di Stasiun CPAR.

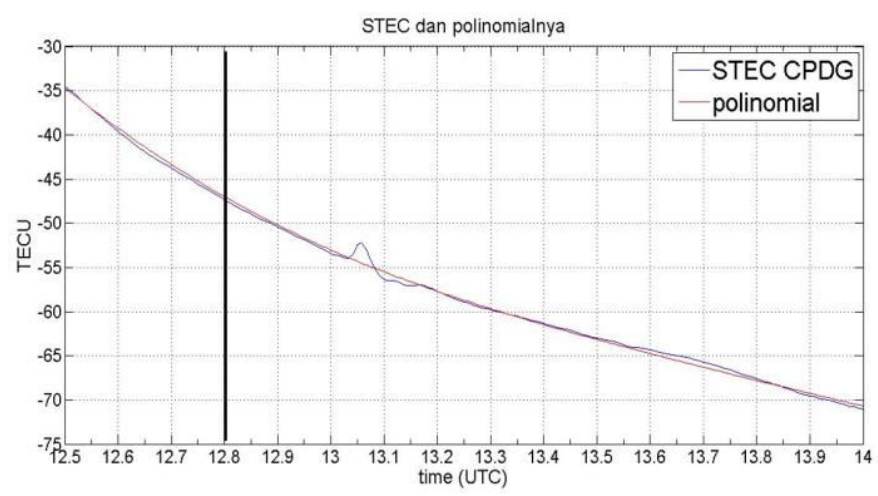

Gambar 9. STEC dengan Polinomial Pangkat Enam di Stasiun CPDG. 


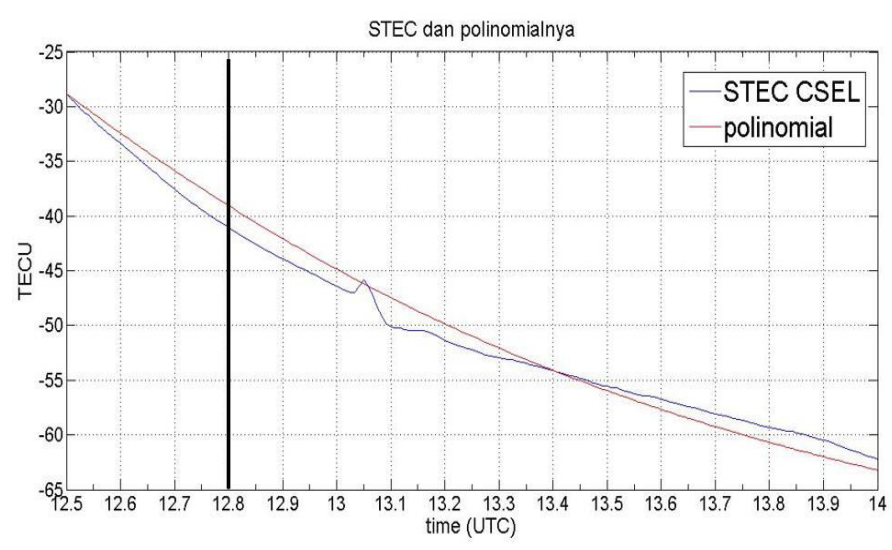

Gambar 10. STEC dengan Polinomial Pangkat Enam di Stasiun CSEL.

Gambar 6 s/d 10 adalah hasil plotting nilai STEC dari satelit GPS nomor 17 dengan data polinomial pangkat enamnya yang terdapat di setiap stasiun pengamatan. Garis hitam vertikal menunjukkan waktu terjadinya gempa, yaitu pukul 12:49 UT yang dalam grafik dinyatakan dalam satuan desimal. Nilai STEC digambarkan dengan garis warna merah, dan untuk nilai polinomial pangkat enam digambarkan dengan garis warna biru. Selisih antara nilai STEC dan polinomial pangkat enam tersebut nantinya digunakan untuk menghitung nilai VTEC yang ada di ionosfer.

Berikut adalah hasil plotting VTEC dari semua stasiun:

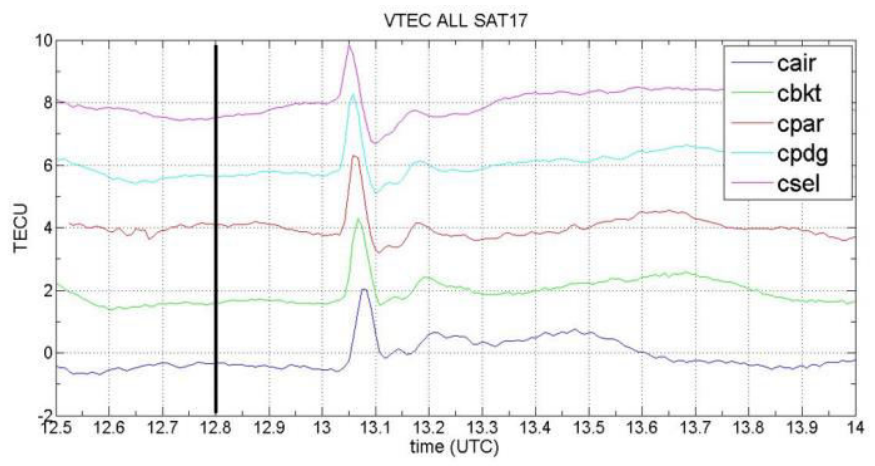

Gambar 11. Nilai VTEC Satelit GPS Nomor 17 di Semua Stasiun Saat Gempa Tanggal 2 Maret 2016.

Dari gambar 11 dapat dilihat nilai anomali TEC satelit GPS di setiap stasiun pengamatan, nilai anomali tersebut berkisar antara $2-3,5$ TECU. Dengan nilai di masing-masing stasiun pengamatan yaitu, CAIR: 2 TECU; CBKT: 2,3 TECU; CPAR: 2,5 TECU; CPDG: 3 TECU; CSEL: 3,5 TECU. Perbedaan besarnya anomali TEC yang terekam tersebut bergantung pada lokasi receiver CORS-GPS. Nilai yang menunjukkan anomali TEC terbesar adalah pada stasiun reciver yang terletak lebih dekat dengan lokasi gempa, yaitu stasiun CSEL yang mencapai 3,5TECU. Dalam penelitian ini juga dihitung nilai anomali TEC satelit Glonass, hasilnya adalah sebagai berikut:

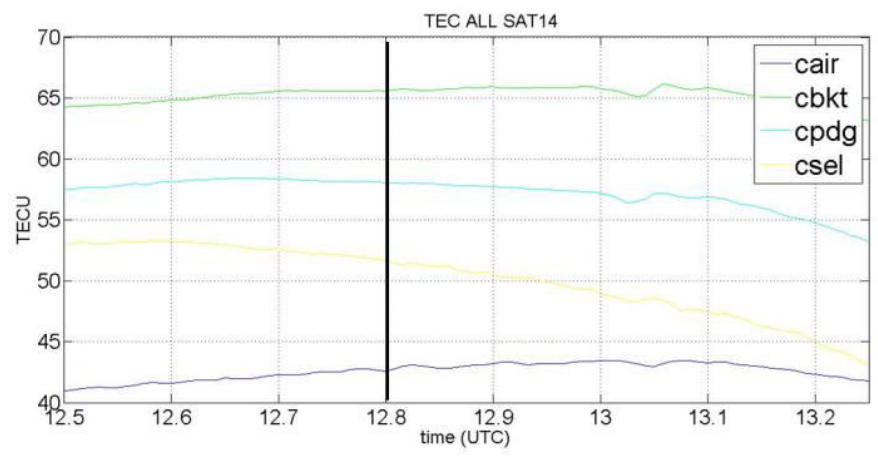

Gambar 12. STEC Satelit Glonass Nomor 14 di Semua Stasiun Pengamatan pada Tanggal 2 Maret 2016.

Gambar 12 menunjukkan bahwa fluktuasi TEC terjadi mulai 11 menit setelah gempa, sama seperti fluktuasi TEC yang terdapat pada pengamatan menggunakan satelit GPS. Kemudian dilanjutkan menghitung nilai anomali TEC.

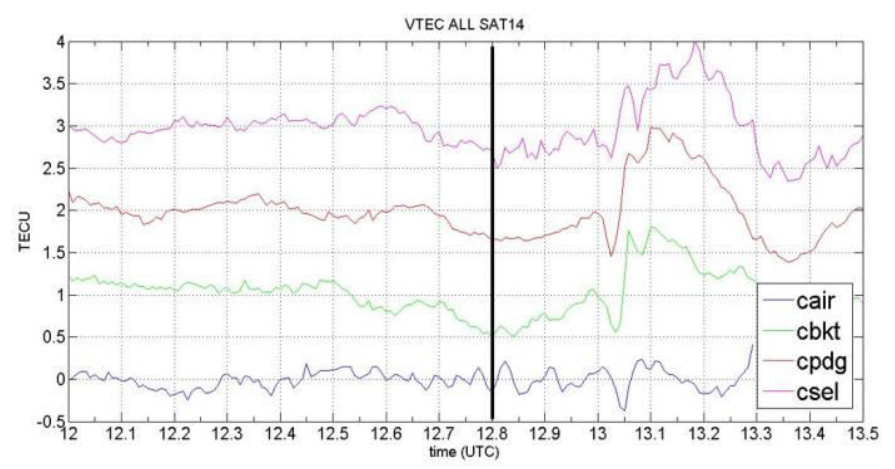

Gambar 13. Nilai VTEC Satelit Glonass Nomor 14 di Semua Stasiun Saat Gempa Tanggal 2 Maret 2016.

Dari gambar 13 dapat dilihat nilai anomali TEC satelit Glonass di setiap stasiun pengamatan, nilai anomali tersebut berkisar antara 0,5 - 1,7 TECU. Dengan nilai di masingmasing stasiun pengamatan yaitu, CAIR: 0,5TECU; CBKT: 1,5 TECU; CPDG: 1,5 TECU; CSEL: 1,7 TECU. Perbedaan besarnya anomali TEC yang terekam tersebut bergantung pada lokasi receiver. Nilai yang menunjukkan anomali TEC terbesar adalah di stasiun reciver yang terletak lebih dekat dengan lokasi gempa, yaitu stasiun CSEL yang mencapai 1,7TECU.

\section{KESIMPULAN}

Berdasarkan pengolahan dan analisis data yang telah dilakukan, kesimpulan yang penulis dapatkan adalah sebagai berikut:

1. Perubahan yang terjadi di ionosfer akibat gempa bumi Sumatra Barat tanggal 2 Maret 2016 adalah terdapat anomali TEC dari pengolahan data satelit GPS dan Glonass, dimana anomali tersebut muncul 11 sampai 15 menit setelah gempa.

2. Besar perubahan TEC yang di rekam satelit GNSS di setiap stasiun pengamatan pada saat gempa bumi adalah:

a. Dari satelit GPS Nomor 17

- CAIR : 2 TECU

- CBKT : 2,3 TECU 
- CPAR : 2,5 TECU

- CPDG : 3 TECU

- CSEL : 3,5 TECU

b. Dari satelit Glonass Nomor 14

- CAIR : 0,5 TECU

- CBKT : 1,5 TECU

- CPDG : 1,5 TECU

- CSEL : 1,7 TECU

\section{DAFTAR PUSTAKA}

[1] L. Handayani, H. Permana, and E. Z. Gaffar, "Segmentasi Tektonik Aktif pada Lempeng Mikro Sumatra Bagian Utara (Aceh) Ditinjau dari Sebaran Episenter Gempa Bumi," J. Lingkung. dan Bencana
Geol., vol. 3, no. 2, pp. 71-77, 2012.

[2] H. Subakti, "Analisis Variasi GPS-TEC yang Berhubungan dengan Gempabumi Besar di Sumatra," Institut Teknologi Bandung, 2008.

[3] Cahyadi, M. Nur, and K. Heki, "Ionospheric Disturbance of The 2007 Bengkulu and the 2005 Nias Earthquake, Sumatra, observed with a Regional GPS Network," J. Geophys. Res., vol. 118, pp. 111, 2013.

[4] Cahyadi and M. Nur, "Near-Field Coseismic Ionospheric Disturbances of Earthquakes In and Around Indonesia," Hokkaido University, 2014.

[5] L. Septiningrum, "Analisis Perubahan Ionosfer Akibat Gempa Mentawai Tahun 2010," Institut Teknologi Sepuluh Nopember, 2016

[6] Badan Informasi Geospasial, "Inacors BIG," 2017. [Online]. Available: http://inacors.big.go.id/spiderweb/ frmIndex.aspx. 